\title{
PENGARUH STATUS KESEHATAN TERHADAP HASIL BELAJAR SISWA SD YPK 14 MARANATHA KOTA MANOKWARI
}

\author{
Ruth Faidiban', Hosiana Sombuk ${ }^{2}$ \\ ${ }^{1}$ Jurusan Keperawatan Politeknik Kesehatan Sorong \\ ${ }^{2}$ Prodi Diploma III Keperawatan Manokwari \\ Email : ruth.faidiban@ymail.com
}

\begin{abstract}
Children will develop their abilities both in learning, interacting socially outside the family environment, this happens in the school environment. Parents are required to be able to prepare their children well before entering the school environment, this is so that children can follow the learning process well. School learning outcomes are strongly influenced by the general abilities measured by the intelligence quotient. The purpose of this study was to identify the effect of health status on the learning outcomes of students of the 14th Maranatha YPK Elementary School in Manokwari City. The population in this study were all students in grades 3,4 and 5. Samples were 103 students. The sampling technique is total sampling. The results showed that the health status of students was healthy $78 \%$, while the learning outcomes of $74 \%$ were quite good, the results of the analysis showed no effect on health status on student learning outcomes in odd semester with the results of $p>0.05(p=0.8)$ in even semester and $p>$ 0.05 ( $p=0.5)$. It is still necessary to improve the health status of students by emphasizing more on school health efforts in detecting students' health when health problems occur or suffer from illness.
\end{abstract}

Keywords: health status, learning outcomes

\section{ABSTRAK}

Anak akan mengembangkan kemampuannya baik dalam belajar, berinteraksi sosial diluar lingkungan keluarga hal ini terjadi dalam lingkungan sekolah. Orangtua dituntut harus dapat mempersiapkan anaknya dengan baik sebelum masuk kedalam lingkungan sekolah, hal ini dimaksudkan agar anak dapat mengikuti proses pembelajaran dengan baik. Hasil belajar disekolah sangat dipengaruhi oleh kemampuan umum yang diukur oleh intelligence quotient. Tujuan penelitian ini untuk mengidentifikasi pengaruh status kesehatan terhadap hasil belajar siswa SD YPK 14 Maranatha Kota Manokwari. Populasi dalam penelitian ini adalah seluruh siswa kelas 3,4 dan 5. Sampel berjumlah 103 siswa. Tehnik sampling adalah total sampling. Hasil penelitian menunjukan status kesehatan siswa yang sehat $78 \%$, sedangkan hasil belajar 74\% cukup baik, hasil analisis menunjukkan tidak ada pengaruh status kesehatan terhadap hasil belajar siswa pada semester ganjil dengan hasil $\mathrm{p}>0.05(\mathrm{p}=0,8)$ pada semester genap dan $\mathrm{p}>0.05$ $(\mathrm{p}=0,5)$. Masih diperlukan peningkatan status kesehatan siswa dengan lebih menekankan pada usaha kesehatan sekolah dalam mendeteksi kesehatan siswa ketika terjadi gangguan kesehatan atau menderita sakit.

Kata kunci : status kesehatan, hasil belajar

\section{PENDAHULUAN}

Kesehatan yang baik akan memberi dampak positif pada prestasi seorang siswa. Tentunya dengan prestasi yang baik akan mempengaruhi kemampuan siswa baik dalam perilaku, sikap, psikomotor bahkan pengetahuannya dalam menyerap ilmu-ilmu pengetahuan yang dipelajari di bangku sekolah yang dapat nilai. Salah satu penentu keberhasilan siswa mencapai prestasi dapat diprediksi dengan pengukuran intelegensi. Namun menurut Muhibbin, (2010) prestasi belajar siswa bukan semata-mata karena kecerdasan siswa saja tetapi ada faktor lain yang dapat mempengaruhi hasil belajar tersebut.

Faktor-faktor yang menentukan keberhasilan hasil belajar seorang anak di sekolah formal antara lain : kesehatan fisik, maturitas emosional, kemampuan berbahasa dan pengetahuan umum sesuai dengan usianya. Standar yang biasa ditentukan dalam kurikulum suatu sekolah antara lain : standar fisik, intelektual dan perkembangan sosial. Secara umum beberapa faktor yang harus diperhatikan dalam mempersiapkan seorang anak untuk masuk sekolah adalah: genetik, umur, 
gender, bobot lahir dan lahir sebelum waktunya, kondisi fisik dan keadaan sekitar keluarga. Kesiapan seorang anak dengan memperhatikan beberapa faktor tersebut diatas diharapkan dapat mengantisipasi kegagalan anak dalam proses pembelajaran di sekolah.

Kegagalan anak sekolah yang mengalami gangguan kesehatan dapat menurunkan kinerja secara individual dan memengaruhi kinerja kelompoknya, hal ini dapat menurunkan pendapatan perkapita negara. Gangguan kesehatan pada anak sekolah merupakan salah satu penyebab menurunnya kemampuan bernalar dan fokus atau perhatian seseorang, serta rendahnya prestasi anak sekolah karena mengalami kesulitan dalam menfokuskan perhatian pada subyek yang dipelajari, dampak negatif lain yang ditimbulkan oleh gangguan kesehatan adalah imunitas berkurang sehingga menyebabkan tubuh mudah terserang penyakit, serta kemampuan berpikir kritis juga menurun.

Tujuan mengidentifikasi "Pengaruh Status Kesehatan Terhadap Hasil Belajar Siswa di SD YPK 14 Maranatha Kota Manokwari, Tahun Ajaran 2017/2018. Diharapkan kesehatan jasmani dari siswa siswi SD YPK 14 Maranatha Kota khusus kelas 3, 4,dan 5 pada tahun 2018, terjaga kesehatannya sehingga dapat mengikuti proses belajar di kelas masingmasing dengan demikian dapat menunjang hasil belajar maupun kenaikan kelas.

Kesiapan sekolah adalah: kesiapan anak untuk bersekolah. Kemampuan anak dapat menggambarkan kemandiriannya secara jasmani, rohani dan psikomotornya ketika akan berinteksi dengan siswa lain yang akan bergaul atau berinteraksi pada suatu institusi pendidikan. Kesehatan fisik, maturitas emosional, kemampuan berbahasa, dan pengetahuan umum sesuai usianya yang merupakan faktor-faktor yang menentukan keberhasilan seorang anak nantinya di sekolah formal (Indriyani SAK, Soetjiningsih 2017).

Kesiapan sekolah adalah kesiapan anak untuk belajar sesuai standar fisik, intelektual dan perkembangan sosial, sehingga anak tersebut mampu memenuhi standart yang ditentukan kurikulum sekolah. Kesiapan sekolah tidak hanya terbatas kesiapan anak saja, melainkan juga keluarga, lingkungan rumah, sekolah dan masyarakat.

\section{METODE}

Penelitian ini merupakan penelitian deskriptif analitik, dengan menggunakan pendekatan Cross Sectional. Penelitian ini menyelidiki pengaruh status kesehatan terhadap hasil belajar siswa SD YPK 14 Maranatha Kota Manokwari. Dilaksanakan pada bulan September - November 2018 di SD YPK 14 Maranatha Kota Manokwari, subyek penelitian adalah siswa-siswi SD YPK 14 Maranataha Kota yang terdiri dari tiga tingkatan ( kelas 3,4 dan 5), berjumlah 103 siswa. Tehnik sampling total sampling. Pengumpulan data sekunder dari absensi siswa semester ganjil dan genap, hasil belajar dari nilai raport semester ganjil dan genap tahun ajaran 2017/2018 Analisis uji statistic mengunakan Chi Square.

\section{HASIL}

Tabel 1. Analisis pengaruh status kesehatan terhadap hasil belajar siswa SD YPK 14 Maranatha Kota Manokwari tahun 2018

\begin{tabular}{lllllllll}
\hline & & & & & \multicolumn{4}{c}{ Hasil Belajar } \\
\hline & & \multicolumn{1}{c}{ Baik } & \multicolumn{2}{c}{ Cukup } & \multicolumn{2}{c}{ Kurang } & $p$ \\
\cline { 3 - 7 } & $\mathrm{n}$ & $\%$ & $\mathrm{n}$ & $\%$ & $\mathrm{n}$ & $\%$ & \\
\hline Status & Sakit & 0 & 0 & 9 & 9 & 9 & 9 & 0,8 \\
Kesehata & Sehat & 0 & 0 & 41 & 40 & 44 & 4 & \\
$\mathrm{n}$ & & & & & & & 2 & \\
\hline Jumlah & & 0 & 0 & 50 & 49 & 53 & 5 & \\
& & & & & & & 1 & \\
\hline
\end{tabular}

Tabel 2. Analisis pengaruh status kesehatan terhadap hasil belajar siswa SD YPK 14 Maranatha Kota Manokwari tahun 2018

\begin{tabular}{lllllllll}
\hline & \multicolumn{8}{c}{ Hasil Belajar } \\
\hline & & \multicolumn{1}{c}{ Baik } & \multicolumn{2}{c}{ Cukup } & \multicolumn{2}{c}{ Kurang } & $p$ \\
\cline { 3 - 8 } & $\mathrm{n}$ & $\%$ & $\mathrm{n}$ & $\%$ & $\mathrm{n}$ & $\%$ & \\
\hline Status & Sehat & 0 & 0 & 68 & 66 & 10 & 9,7 & 0,5 \\
Kesehatan & Sakit & 0 & 0 & 10 & 9,7 & 15 & 14,5 & \\
\hline Jumlah & & 0 & 0 & 78 & 75,7 & 25 & 24,2 & \\
\hline
\end{tabular}




\section{PEMBAHASAN}

Hasil penelitian yang dilakukan pada siswa SD YPK 14 Maranatha Kota menunjukkan bahwa tidak ada pengaruh status kesehatan terhadap hasil belajar siswa kelas 3,4 dan 5 pada semester ganjil dengan melihat hasil uji statistik dimana nilai $p$ value $=0.8$ dan semester genap $p$ value $=0,5$ nilai ini lebih besar dari 0,05 . Walaupun secara statistik tidak bermakna namun secara klinis jumlah siswa yang sakit pada semester ganjil ada sebanyak 18 siswa dan pada semester genap sebanyak 25 siswa, ada peningkatan kondisi sakit pada semester ganjil dan genap, hal ini akan berdampak pada kondisi fisik dan psikologis ketika anak tertinggal pelajaran dan hasil ujian mendapat nilai yang rendah. Siswa dengan status sakit ditetapkan berdasarkan surat keterangan sakit dari dokter yang menangani siswa dengan lama sakit 3-7 hari baik dari Puskesmas maupun Rumah Sakit Umum Manokwari. Hasil penelitian yang didapatkan ini akan berdampak pada kondisi fisik dan psikologis ketika anak tertinggal pelajaran dan selesai ujian mendapat nilai yang rendah. Menurut temuan yang disampaikan Zakky (2018) proses belajar yang dilalui siswa akan dinilai pada akhir proses dengan penilaian dalam bentuk angka, simbol atau huruf pada suatu fase pembelajaran. Dan hasil yang didapatkan mencerminkan kemampuan yang dimiliki oleh seorang siawa.

Sukmadinata (2005), menyatakan bahwa faktor-faktor yang mempengaruhi hasil belajar antara lain: faktor dari dalam individu yang meliputi aspek jasmaniah, aspek rohaniah, dan kondisi intelektual, selain itu faktor lingkungan juga ikut mempengaruhi seperti faktor fisik maupun sosial psikologis yang berada pada lingkungan keluarga, sekolah, dan masyarakat. Sedangkan menurut Achmadi dan Supriyono (2004), faktor-faktor yang mempengaruhi hasil belajar siswa adalah dari faktor internal, yang meliputi faktor jasmaniah (fisiologis) dan faktor psikologis. Dengan demikian dapat disimpulkan bahwa hasil penelitian yang dilakukan di SD YPK 14 Maranatha Kota, sama dengan penelitian Anas (2011) yang tidak ditemukan hubungan yang bermakna antara prestasi belajar dengan kesegaran fisik/jasmani siswa. Dan menurut Indriyani SAK, Soetjiningsih (2017) kesehatan fisik, maturitas emosional, kemampuan berbahasa, dan pengetahuan umum sesuai usianya yang merupakan faktor-faktor yang menentukan keberhasilan seorang anak nantinya di sekolah formal. Dengan demikian dapat disimpulkan bahwa hasil penelitian yang dilakukan di SD YPK 14 Maranatha Kota Manokwari menunjukkan tidak ada pengaruh status kesehatan terhadap hasil belajar siswa.

\section{SIMPULAN}

Tidak ada pengaruh status kesehatan terhadap hasil belajar siswa SD YPK 14 Maranatha Kota Manokwari pada semester ganjil dan semester genap.

\section{SARAN}

Dengan hasil penelitian ini dapat digunakan untuk meningkatkan hasil belajar siswa dengan memperhatikan status kesehatan siswa yang menderita sakit dan mencari solusi bagi siswa yang mengalami keterlambatan dalam menyelesaikan materi yang tidak diikuti. Selain itu dapat memanfaatkan layanan kesehatan lewat usaha kesehatan sekolah dalam melakukan deteksi kesehatan lebih dini dalam meningkatkan kesehatan siswa.

Orang tua dapat membantu anak-anaknya yang sakit dan tidak mengalami ketertinggalan pelajaran karena tidak hadir, dengan berbagai alternatif yang bisa dilakukan misalnya dengan mendapatkan pelajaran tambahan. Selain itu juga orang tua lebih memperhatikan kesehatan anaknya sesuai pertumbuhan dan perkembangannya serta membantu anak dalam belajar.

\section{DAFTAR PUSTAKA}

Anas Sudijono, (2011) Evaluasi Pendidikan, Jakarta Raja Grafindo Persada.

Ahmadi, Abu \& Widodo, (2004) Psikologi Belajar.Jakarta. Rineka Cipta

CH Soetjiningsih, (2017) Psikologi dan Kesehatan Mental 2, Fakultas Psikologi Univ. Satyawacana Salatiga

Muhibbin Syah. (2010) Psikologi Pendidikan dengan pendekatan baru. Bandung:PT Remaja Rosdakarya, 
Soetjiningsih, IG. N Gde Ranuh, Tumbuh Kembang Anak, Edisi 2 Penerbit EGC.

Jakarta 2017. 